\title{
Results of the surgical correction of urinary stress incontinence according to the type of transobturator tape utilized
}

\author{
Bárbara Padilla-Fernández ${ }^{1}$, Maria Begoña García-Cenador ${ }^{2}$, Ana Gómez-García ${ }^{3}$, \\ José Antonio Mirón-Canelo ${ }^{4}$, Ángel Gil-Vicente ${ }^{1}$, Juan Miguel Silva-Abuín ${ }^{1}$, \\ María Fernanda Lorenzo-Gómez ${ }^{1}$ \\ ${ }^{1}$ Department of Urology. University Hospital of Salamanca; \\ ${ }^{2}$ Department of Surgery, University of Salamanca; \\ ${ }^{3}$ Family and Community Medicine. University Hospital of Salamanca; \\ ${ }^{4}$ Department of Preventive Medicine and Public Health, University of Salamanca.
}

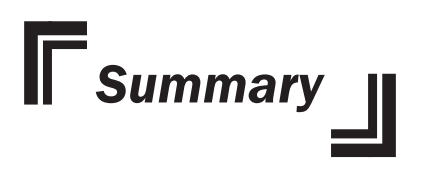

Objectives: To analyze the short and long term results of tapes of different materials used to treat stress urinary incontinence (SUI). A secondary objective was to evaluate the ability to adjust the tape after implantation.

Materials and methods: Retrospective chart review of 355 patients with SUI operated between March 2003 and October 2011. Eight different types of transobturator tapes were used: Gynecare TVT-O ${ }^{\circledR}$, Monarc $^{\circledR}$, SAFYRE $^{\circledR}$, Contasure KIM $^{\circledR}$, I-Stop $^{\circledR}$, DynaMesh $^{\circledR}$, Aris $^{\circledR}$ Bandellete and Swing-band ${ }^{\circledR}$. Results and complications were recorded.

Results: The mean age at operation was 61 years. Correction of SUI was achieved in $87.88 \%$ of cases. The best results were obtained with Contasure $\mathrm{KIM}^{\circledR}$ (98.26\% continence). The tape was well tolerated and was elastic enough to be able to be adjusted 48-72 hours after implantation without deformation. Slings with macropores and over lock stiches on the superior and inferior borders presented the lower rates of postoperative urinary retention, pain, peri- or postoperative bleeding and urinary tract infections.

Conclusions: Transobturator tension free tapes require a short operation time and have a low complication rate. The possibility of adjustment in the early postoperative period increases the success rate and reduces complications. Knotless meshes with macropores and over lock stiches appear to be better balanced, are quite resistant to stretching and deformation when readjusted after implantation and present a low infection rate.

KEY WORDS: Urinary tract; Polypropylene; Suburethral transobturator tape; Physical characteristics.

\section{INTRODUCTION}

The International Continence Society defines urinary incontinence as the involuntary loss of urine per urethra that can be objectively demonstrated and that causes social or hygienic problems $(1,2)$ and affects the psychological, social and sexual life of the patient (3).

In Spain the prevalence of urinary incontinence in persons older than 60 years was $40 \%$ in 2003 . Others reported a $35.1 \%$ prevalence of incontinence in persons older than 64 years of age, namely 23\% in women older than 18 years of age, $20 \%$ in women of working age and 14\% among women between 40 and 64 years of age $(4,5)$.

The surgical treatment of stress urinary incontinence (SUI) in females has changed over time. Delancey pointed out the importance of the suburethral sector in any successful surgical strategy for SUI (6). In 2001, Delorme reported the transobturator approach (TOT) which consists of placing a mesh through the obturator foramen behind the mid-urethra (7). 
There is a multitude of products available for the correction of SUI. Previous studies have focused on the durability and resistance of the materials but few have addressed clinical results in the short and long term for the various types of tapes available.

The goals of our study were to analyze the results obtained with different meshes of various types of materials.

\section{Materials AND MEthodS}

We conducted a retrospective, multicentric study in a cohort of 363 patients with SUI who underwent TOT implantation between March 2003 and October 2011 at the University Hospital of Salamanca and the Hospital Santísima Trinidad of Salamanca.

A standard study protocol which consisted of anamnesis, general and uro-gynecological physical examination, the ICIQ-SF incontinence questionnaire (6) and the King's Health or SF36 quality of life tests $(7,8)$. Routine laboratory tests, urine culture and renal and bladder ultrasonography were performed as well. Cystography, urodynamic studies, urine cytology and cystoscopy were performed when indicated according to standard practice.

Surgical procedure: All procedures were performed in a short stay unit with 1 night of hospitalization under spinal anesthesia and under antibiotic coverage. The patient was placed in the dorsal lithotomy position with hyperabducted thighs. A 16 Ch balloon catheter with $20 \mathrm{ml}$ in the balloon was inserted in the bladder. Extensive hydrodissection between the anterior vaginal wall and the urethra was done. The specially designed fine atraumatic needles were introduced from outside in (Figure 1). The tape was attached to the needle and the tape was passed from inside out (Figure 2). A vaginal pack was left in place for 12-24 hours. Forty-eight to 72 hours later, a revision was performed to evaluate the adjustment of the tape.

Postoperative controls were performed at one month and one year with anamnesis, and repeat ICIQ/SF and Kings Health or SF-36 questionnaires.

We compared the results according to the 8 different types of tape utilized.

- Gynecare TVT-O ${ }^{\circledR}$ (Ethicon): Polypropylene mesh with macro pores. Low density woven mesh (60\% porosity).

- Monarc ${ }^{\circledR}$ (AMS): Polypropylene mesh with $1 \mathrm{~mm}$ diameter macro pores. Low density woven mesh (46\% porosity). It has acceptable elasticity.

- SAFYRE ${ }^{\circledR}$ (Promedon) (6): Monofilament polypropylene mesh with self- retaining columns of polydimethylsiloxane-polymer

- Contasure $\mathrm{KIM}^{\circledR}$ (Neomedic International): Knotless monofilament polypropylene tape with over lock stitches in the superior and inferior borders as well as in the middle of the tape.

- I-Stop ${ }^{\circledR}$ (CL Medical): Polypropylene mesh with macro pores with spiral borders to maintain rigidity, allow fibrosis and minimize the risk of erosion and migration.

- DynaMesh ${ }^{\circledR}$ (FEG Textiltechnik): Mesh made of monofilament polyvinylidene fluoride with smooth atraumatic edges.
- Aris ${ }^{\circledR}$ Bandelette (Coloplast): Woven monofilament polypropylene mesh with macropores.

- Swing-band ${ }^{\circledR}$ (THT bioscience): Light or ultra-light monofilament polypropylene tapes with pores 0.7 to $1.5 \mathrm{~cm}$ with low elasticity.

We recorded effectiveness and complications taking into account not only continence but overall wellbeing of the patients. Complications included lesions to other organs, hemorrhage, hematoma formation, urinary retention, and the development of new urinary incontinence.

The data were recorded in an Excel $^{\circledR}$ worksheet and imported to NCSS ${ }^{\circledR}$ for statistical analysis. Fisher exact test, Wilcoxon non-parametric test for 2 samples, Friedman non-parametric test for more than 2 samples, Student's t-test and Pearson Chi-square test were used.

\section{Figure 1.}

Introduction of the fine atraumatic needle from outside-in.

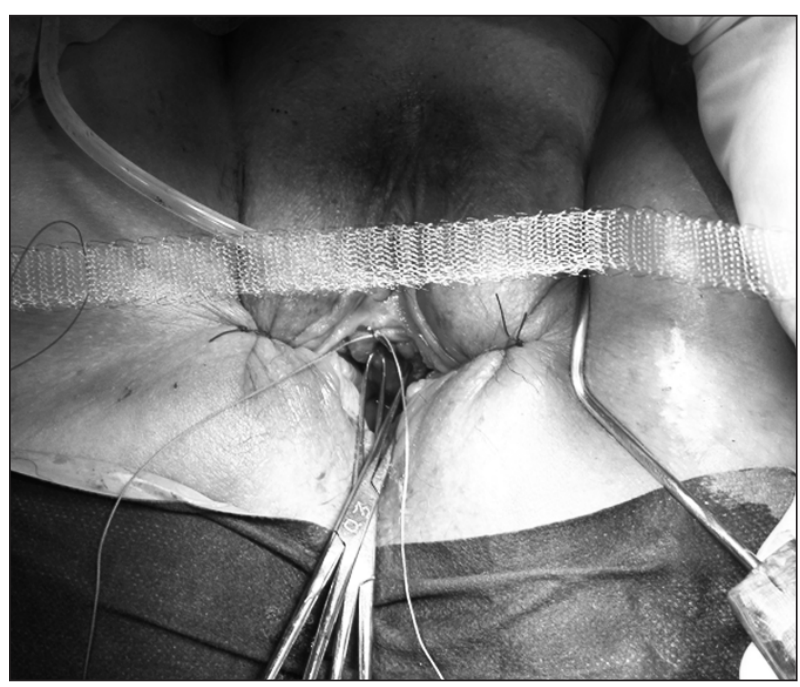

Figure 2.

Suburethral tape passed through both obturator foramina.

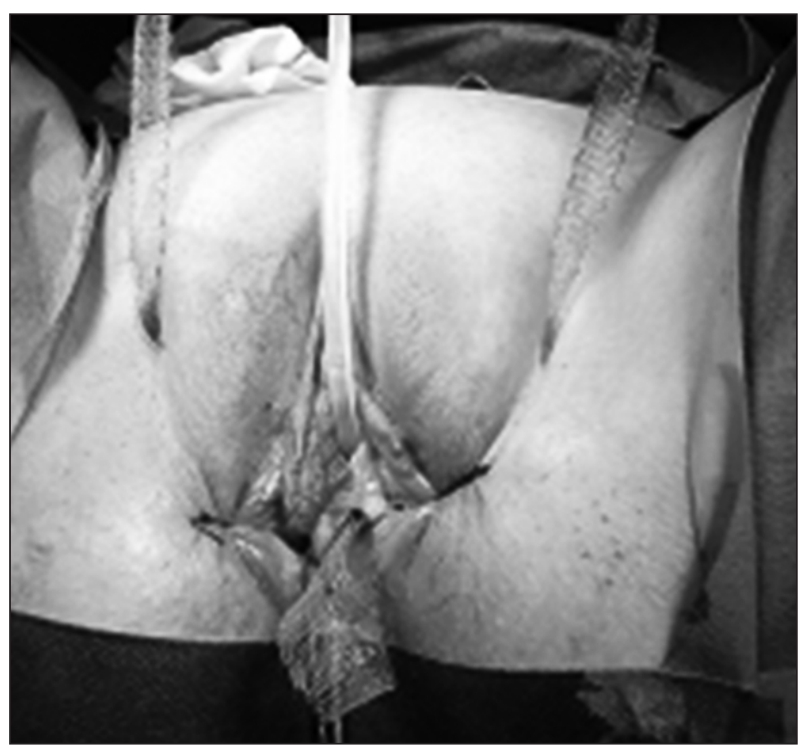


Figure 3.

Suburethral tapes used.

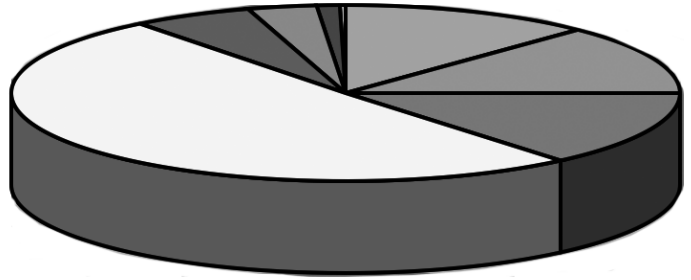

$\square$ Monarc

$\square$ Safyre

$\square$ Gynecare

$\square$ KIM System $\square$ I-Stop

口Dinamesh PVDF

$\square$ Aris

$\square$ Swing-band

\section{RESULTS}

We implanted TOT on 355 women with SUI. The median age was 61.16 years (range 41-81 years).

Incontinence was corrected in $87.88 \%$ of the patients, the rest remained incontinent.

The past medical and surgical histories and concomitant treatments were not different among the 8 groups.

Monarc ${ }^{\circledR}$ tape was used in 42 patients, Safyre ${ }^{\circledR}$ in 44 , Gynecare $^{\circledR}$ in 47, Kim System ${ }^{\circledR}$ in 173, I-Stop ${ }^{\circledR}$ in 20, Dinamesh $^{\circledR}$ in 11 , Aris $^{\circledR}$ in 4 and Swing-band ${ }^{\circledR}$ in 4 (Figure 3).

Contasure $\mathrm{KIM}^{\circledR}$ presented the best success rate. $98.26 \%$ of the women were continent after the operation and tolerated the procedure well. The tape was elastic enough to allow adjustment without deformation (Table 1).

The success rate with Monarch ${ }^{\circledR}$ tapes was overall good (90.47\%); however, this tape was inadequate when adjustments were needed because it became elongated and deformed when applying tension.

In 4 of the 44 patients who underwent implantation of Safyre ${ }^{\circledR}$ tape the retention column became detached from the mesh resulting in incontinence.
There was local discomfort and the patients required local anesthesia for the adjustment.

The success rate for Gynecare ${ }^{\circledR}$ tapes was $82.45 \%$. The tape could be adjusted without deformation. Six of 47 women had acute urinary retention which, when corrected, led to permanent urinary incontinence.

I-Stop ${ }^{\circledR}$, Dynamesh ${ }^{\circledR}$, Aris $^{\circledR}$ and Swing-band ${ }^{\circledR}$ tapes had success rates less than $80 \%$, were not malleable and could not be adjusted after implantation. As a group they were less well tolerated and presented a greater rate of urinary retention.

Tapes with overlock stiches on the superior and inferior edges caused lower rates of postoperative urinary retention $(\mathrm{p}=0.0013)$, patients had less pain $(\mathrm{p}=0.0023)$, intra or post-operative bleeding $(\mathrm{p}=0.00013)$ and urinary tract infections $(\mathrm{p}=0.0045)$.

These tapes also allowed postoperative adjustment. Tapes made of material with macropores and without knots appear to be better balanced, are highly resistant to deformation allowing a correct and effective postoperative adjustment.

Table 1.

Success rate, complications and tolerability associated to the type of mesh used.

\begin{tabular}{|c|c|c|c|c|c|}
\hline \multirow[t]{2}{*}{ Tape } & \multicolumn{2}{|c|}{$\begin{array}{l}\text { Success } \\
\mathrm{N}=319\end{array}$} & \multicolumn{2}{|c|}{$\begin{array}{l}\text { Failure } \\
N=44\end{array}$} & \multirow[t]{2}{*}{ Comments } \\
\hline & $\mathbf{N}$ & $\%$ & $\mathbf{N}$ & $\%$ & \\
\hline - Monarc ${ }^{\circledast}$ & 38 & 90.47 & 4 & 9.53 & $\begin{array}{l}\text { Well tolerated. } \\
\text { Cannot be adjusted because it deforms and elongates. }\end{array}$ \\
\hline - Safyre ${ }^{\circledR}$ & 30 & 68.18 & 14 & 31.82 & $\begin{array}{l}\text { More local discomfort. } \\
4 \text { failures from dissociation of the silicon columns }\end{array}$ \\
\hline - Gynecare ${ }^{\circledR}$ & 47 & 82.45 & 10 & 17.55 & 6 Urinary retentions. 4 urinary incontinences. \\
\hline - Kim System ${ }^{\circledR}$ & 170 & 98.26 & 3 & 1.74 & $\begin{array}{l}\text { No urinary retention. } 3 \text { urinary incontinences. } \\
\text { Elasticity sufficient to allow adjustment without } \\
\text { deformation. Well tolerated. }\end{array}$ \\
\hline - I-Stop ${ }^{\circledR}$ & 14 & 70 & 6 & 30 & 4 Urinary retention. 2 urinary incontinences. \\
\hline $\begin{array}{l}\text { - Dynamesh-SIS direct: } \\
\text { Polyvinylidene Fluoride (PVDF) }{ }^{\circledR}\end{array}$ & 8 & 72.72 & 3 & 27.27 & $\begin{array}{l}\text { Inelastic. Cannot be adjusted. Well tolerated. } \\
1 \text { urinary retention. }\end{array}$ \\
\hline - Coloplast Bandelette Aris ${ }^{\circledR}$ & 3 & 75 & 1 & 25 & Dense, inelastic. Cannot be adjusted. \\
\hline - THT Swing-band ${ }^{\circledR}$ & 3 & 75 & 1 & 25 & Suburethral with less material to anchor to the fascia. \\
\hline
\end{tabular}




\section{Discussion}

The use of biomaterials in Urology is extensive ranging from suture and ligature materials to the use of ureteral and urethral catheters to drain fluids. Within this spectrum are the meshes used to correct SUI which act as permanent prostheses implanted at the level of the midurethra.

The meshes used for this purpose must be biocompatible fulfilling the following conditions (7):

- Should not induce an inflammatory reaction since both an exaggerated inflammatory reaction and the presence of dead spaces between the mesh and surrounding tissues increase the risk of seroma formation. This is the case when the mesh is slowly or not incorporated into the surrounding tissues such as is the case with meshes with micropores or of high density. $(8,9)$.

- Should not induce an allergic reaction since this will lead to rejection and extrusion of the prosthesis (10).

- Should not induce tumor formation.

Experimental studies in rats have shown that type 1 meshes induce the development of a surrounding fibrous capsule which becomes integrated from top to bottom through the pores and small spaces between the monofilaments thus producing a firm anchoring to the surrounding tissues (11).

This peripheral capsule allows future identification and removal of the tape when necessary. The integration of the capsule on the center decreases mechanical irritation and the chances of extrusion. This encapsulation also facilitates a better blood supply which might lead to less chances of infection (11).

Meshes with small pores and without structural homogeneity generate a greater local inflammatory reaction and less collagen synthesis. These meshes induce a foreign body reaction rather than fibrosis with the above mentioned consequences $(12,13)$.

Moalli et al. (14) studied 5 commonly used meshes in the USA for the correction of SIU by the TVT method. The meshes were subjected to traction and elongation to test their resistance and hardness. This study showed that Gynecare ${ }^{\circledR}$ and Monarc ${ }^{\circledR}$ were easily deformed with low loads which would be clinically manifested by elongation and deformation with minimal tensions. The elongation caused by cyclic loads (such as coughing) might be irreversible. On the other hand, these features lessen the probability of erosion or migration and might reduce the risk of urinary retention (14).

The same authors remark that the Gynecare ${ }^{\circledR}$ mesh has an initial region of low hardness which allows the mesh to elongate easily in response to small tensions. This is followed by a transition zone and an area that is very hard. They stated that the mesh increases more than 10\% of the usual length in response to a series of cyclical loads (14). Nevertheless, Neymeyer et al. (15) reported that the Gynecare $^{\circledR}$ tape presents better tolerance to tension and less elongation, that is better integrated despite loads or tension.

Mascarenhas studied in depth the mechanical features of the tapes used to treat SUI and the mechanical properties of the pelvic floor during delivery and in genital prolapse
(16). Her intention was to improve the biomechanical analysis of the pelvic floor tissues and improve understanding of the etiology of pelvic floor dysfunction that leads to the development of meshes and prosthesis. This requires interdisciplinary collaboration including engineers and clinicians (16).

Studies have found significant differences between Aris ${ }^{\circledR}$ and Gynecare ${ }^{\circledR}$ in regards to hardness tested both by tension and compression (17). Others have analyzed the thermal and structural differences of meshes that could in theory influence the development of urethral and vaginal erosions and extrusion. Using calorimetric scanning, infrared spectroscopy and analyzing the geometry and lineal and relative densities it was concluded that there is a direct correlation between the diameter of the fibers, the linear density, the degree of crystallinity, the resistance to flexion and the mechanical properties of the tapes (18).

The ability of tapes to be adjusted postoperatively appears to be related to the resistance and elasticity which are determined by the porosity, density, type of material used to manufacture the tapes as well as the manner in which the filaments are knitted and the interaction with the host.

Overlock stiches at the edges of the mesh confers resistance without decreasing elasticity and malleability. In such tapes elongation in response to tension is less both under physiologic conditions and during adjustments. One must be reminded of the fundamental role of careful patient selection, the investigation of risk factors and the selection of a tape with which the surgeon feels comfortable to achieve a successful correction of SUI (19, 20). The weakness of our study lies in its retrospective nature and the scant number of patients in some groups.

\section{Conclusions}

Surgical correction of SUI with transobturator tape (TOT) is the procedure of choice because of a shorter surgical time and a lower complications rate compared with retropubic tension free tapes (TVT).

With this technique, the possibility of adjustment in the early postoperative period increases the chances of cure and reduces complications.

Macropore meshes without knots and over lock stitches seem to be better balanced, are resistant to elongation and deformation when subjected to the necessary tension for postoperative adjustment. They also present a low rate of infection.

\section{References}

1. Abrahams P, Blaivas J, Stanton S. The standarization of terminology of lower urinary tract function. Scan J Urol Nephrol 1988; 114-5.

\section{International-Continence-Society. Standardization of terminology} of lower urinary tract function. Urol. 1977; 9:237.

3. Serrano R. El 90\% de las IU de esfuerzo se evitan con medidas preventivas. Madrid: Recoletos.es; 2003 [cited 2003 21-10-2003]; http://www.diariomedico.com/edicion/noticia/0,2458,404697,00.html]

4. Médico-Interactivo-Diario-Electrónico-de-la-Sanidad. Más de 
800.000 españoles sufren incontinencia urinaria. Madrid: Meditex, S.L; 2003 [cited 2003]; No 892, del 10 de Enero de 2003

5. Norton P, MacDonald L, Sedgwick P, Stanton S. Distress and delay associated with urinary incontinence, frequency, and urgency in women. Br Med J. 1988; 297:1187-9.

6. Palma P, Riccetto C, Herrmann V, et al. Transobturator SAFYRE sling is as effective as the transvaginal procedure. Int Urogynecol J. 2005; 16:487-91.

7. Galmés Belmonte I, Díaz Gómez E. ¿Son iguales todos los sistemas empleados para corregir la incontinencia urinaria mediante mallas libres de tensión? Actas Urológicas Españolas. 2004; 28:487-96.

8. Cervigni $M$, Natale F. The use of synthetics in the treatment of pelvic organ prolapse. Curr Opin Urol. 2001; 11:429-35.

9. Falconer C, Soderberg M, Blomgren B, Ulmsten U. Influence of different sling materials on connective tissue metabolism in stress urinary incontinent women. Int Urogynecol J Pelvic Floor Dysfunct. 2001; 12(Suppl 2):S19-S23.

10. Debodinance P, Delporte P, Engrand J, Boulogne M. Development of better tolerated prosthetic materials: applications in gynecological surgery. J Gynecol Obstet Biol Reprod. 2002; 31:527-40.

11. Slack M, Sandhu J, Staskin D, Grant R. In vivo comparison of suburethral sling materials. Int Urogynecol J. 2006; 17:106-10.

12. White $R$. The effect of porosity and biomaterial on the healing and long-term mechanical properties of vascular prostheses. Trans Am Soc Artif Intern Organs. 1988; 34:95-100.
13. White R, Hirose F, Sproat R, et al. Histopathologic observations after short-term implantation of two porous elastomers in dogs. Biomaterials. 1981; 2:171-6.

14. Moalli PA, Papas N, Menefee S, et al. Tensile properties of five common used mid-urethral slings relative to the TVTTM. Int Urogynecol J. 2008; 19:655-63.

15. Neymeyer JN, Abdul-Wahab WAW, Spethmann JS, et al. Material laboratory testing of suburethral mesh slings: a comparison of their static and dynamic properties. Eur Urol Suppl. 2008; 7:316.

16. da Silva-Filho A, Martins P, Parente M, et al. Translation of biomechanics research to urogynecology. Arch Gynecol Obstet. 2010; 282:149-55.

17. Afonso J, Martins P, Girao M, et al. Mechanical properties of polypropylene mesh used in pelvic floor repair. Int Urogynecol J Pelvic Floor Dysfunct. 2008; 19:375-80

18. Afonso J, Jorge R, Martins P, et al. Structural and thermal properties of polypropylene mesh used in treatment of stress urinary incontinence. Acta Bioeng Biomech. 2009; 11:3.

19. Lorenzo Gómez MF, Gómez García A, Padilla Fernández B, et al. Factores de riesgo de fracaso de la corrección de la incontinencia urinaria de esfuerzo mediante cinta suburetral transobturatriz. Actas Urol Esp. 2011; 35:454-8.

20. Díez-Calzadilla NA, March-Villalba JA, Ferrandis C, et al. Factores de riesgo en el fracaso de la reparación quirúrgica del prolapso de suelo pelviano. Actas Urol Esp. 2011; 35:448-53.

\title{
Correspondence
}

Bárbara Padilla-Fernández, PhD, MD (Corresponding Author) padillaf83@hotmail.com

Juan Miguel Silva-Abuin, PhD, MD

elviso@usal.es

Ángel Gil-Vicente, MD

mflorenzogo@yahoo.es

María Fernanda Lorenzo-Gómez, PhD, MD

mflorenzogo@yahoo.es

Department of Urology, University Hospital of Salamanca

Paseo de San Vicente, 58-182 - 37007 Salamanca, Spain

María Begoña García-Cenador, PhD, Biol

mbgc@usal.es

Department of Surgery, University of Salamanca

37007 Salamanca, Spain

\author{
Ana Gómez-García, PhD, MD \\ agogarci@hotmail.com \\ Family and Community Medicine, University Hospital of Salamanca \\ 37007 Salamanca, Spain \\ José Antonio Mirón-Canelo, PhD, MD \\ miroxx@usal.es \\ Department of Preventive Medicine and Public Health \\ University of Salamanca - Campus Miguel de Unamuno \\ Faculty of Medicine \\ C/ Alfonso X El Sabio, s/n - 37007 Salamanca, Spain
}

